\title{
Heavy Metals and Arsenic in Soil and Cereal Grains and Potential Human Risk in the Central Region of Peru
}

\author{
María Custodio ${ }^{1 *}$, Richard Peñaloza', Edith Orellana², Manuel A. Aguilar-Cáceres², \\ Edith M. Maldonado-Oré ${ }^{3}$
}

1 Universidad Nacional del Centro del Perú, Facultad de Medicina Humana, Centro de Investigación en Medicina de Altura y Medio Ambiente, Av. Mariscal Castilla №3909, Huancayo, Perú

2 Universidad Nacional del Centro del Perú, Facultad de Ciencias Forestales y del Ambiente, Av. Mariscal Castilla Nº3909, Huancayo, Perú

3 Universidad Nacional del Centro del Perú, Facultad de Antropología, Av. Mariscal Castilla N 3909, Huancayo, Perú

* Corresponding author's e-mail: mcustodio@uncp.edu.pe

\begin{abstract}
The objective of this study was to analyze the content of heavy metals and arsenic in soil and cereal grains as well as to evaluate the possible human risk in the central region of Peru. The soil samples of corn and barley grains were collected from seven agricultural zones and the concentrations of $\mathrm{Cu}, \mathrm{Fe}, \mathrm{Pb}, \mathrm{Zn}$ and As were determined with the method of atomic absorption flame spectrophotometry. PERMANOVA showed that the effect of the type of crop and the sampling zone significantly influence the concentrations of heavy metals and As in soil and corn and barley grains $(\mathrm{p}<0.05)$. PCA for heavy metals and As in soil and grain samples of the cereals studied showed that the first two main components represented $81.03 \%$ and $94.77 \%$ of the total variance, respectively. Hazard Quotient (HQ) for ingestion was the most significant. The HQ values of $\mathrm{Pb}$ and $\mathrm{As}$ in crop soils indicated that detrimental health effects are unlikely $(\mathrm{HQ}<1)$. The soil hazard index $(\mathrm{HI})$ values of both crops did not exceed the threshold value of $1(\mathrm{HI}<1)$. The carcinogenic risk level $(\mathrm{CR})$ of As from ingestion of corn and barley crop soils contaminated by As was higher in children than in farmers and adults. The bioconcentration factor (BCF) of As was higher in barley grains than in corn grains. The THQ of As exceeded the target value of 1 in $100 \%$ of the barley and corn sampling sites. The RC of As in grains exceeded the acceptable risk level of $10^{-6}$ in all sampling zones.
\end{abstract}

Keywords: soil, cereals, heavy metals, arsenic, human risk.

\section{INTRODUCTION}

Environmental contamination by heavy metals and metalloids is a global problem of great concern in today's society, due to the rapid growth of urbanization, changes in land use and industrialization (Rai et al., 2019). The concentration of these metals in the soil has increased exponentially in the last three decades (Kumar and Prasad, 2018) and contributed to soil contamination as a consequence. This effect generated by toxic metals is one of the worrying aspects of this growing ecological and health crisis, due to their non-biodegradability and persistence. These metals enter the food chain through contaminated soil, water and atmospheric deposition (França et al., 2017). Soil contamination is accelerated by the continuous and excessive use of agrochemicals, such as pesticides, phosphate fertilizers and fertilizers, and the use of wastewater for irrigation (Branco et al., 2015). The accumulation of toxic metals in the soil negatively affects food security and poses a threat to the human and animal health. The ingestion of soil by livestock may also represent another entry point of toxic metals into the food chain (Cai et al., 2009).

Vegetables can absorb toxic metals from contaminated soils, wastewater and by atmospheric 
deposition of particles from various sources. The absorption of metals by roots is determined by several factors, such as metal content in the soil, $\mathrm{pH}$ and type of soil, organic matter, cation exchange capacity, species and genotype (Fan et al., 2017). The accumulation of toxic metals in the food chain can be dangerous for the human health. Prolonged ingestion of the plants contaminated with toxic metals can alter biochemical processes, lead to their accumulation in the liver and kidneys, and induce toxicity in many organs of the human body (Rai et al., 2019). However, the toxicity of toxic metals depends on the forms and routes of exposure, the interruptions of intracellular homeostasis as well as oxidative deterioration of biological macromolecules (Woldetsadik et al., 2017).

Globally, numerous investigations have reported on the contamination of agricultural soils with toxic metals (Hang et al., 2009; Branco et al., 2015). These metals can be easily absorbed and accumulate in high concentrations in the edible parts of vegetables. Very high levels of toxic metals have been found in tomatoes, carrots, cabbage, turnips, radishes, cauliflowers, cucumbers, spinach and other vegetables (Yang et al., 2009; Antoniadis et al., 2017). Crops such as rice, corn, wheat, potatoes, and soybeans irrigated with wastewater can be a significant source of toxic metals in the human and animal diet (Amin et al., 2013). Other studies reveal that the absorption and accumulation of toxic metals not only differs between species, but also within each species (Zhu et al., 2007; Shahid et al., 2018).

The ingestion of food contaminated with toxic metals is an important route that contributes to approximately $90 \%$ of human exposure (Khan et al., 2013). The gastrointestinal tract is the main route of $\mathrm{Pb}$ absorption and adults absorb about $10 \%$ of the lead content in food, while children absorb 3 or 4 times more $\mathrm{Pb}$ (Bui et al., 2016). Most $\mathrm{Pb}$ is concentrated in bones, teeth, and fatty tissue, leading to the depletion of essential nutrients and immune defenses. The toxicity at the risk dose level of $\mathrm{Pb}$ can cause increased blood pressure, nervous system difficulties, and bone weakness. It can also negatively affect mental development, causing neurological and cardiovascular disorders in humans (Zhou et al., 2016). In adults, it can cause kidney dysfunction, hypertension, and other serious diseases of the liver, lung, nervous system, and immune system (Chaoua et al., 2018). At excessive levels, As can cause cancer, skin, respiratory, cardiovascular, gastrointestinal, hematological, liver, kidney, neurological, developmental, reproductive and immune problems (Zhao et al., 2014; Shah et al., 2020).

The human exposure to contaminated food is a concern worldwide. In the South American context, food safety has become an issue of great interest due to the high levels of heavy metals in the environment, which reveals the need to assess food safety with respect to the presence of non-essential metals in the edible parts of principal food crops (Arisseto-Bragotto et al., 2017). In Peru, this type of assessment is necessary for crops in the areas with limited availability of good quality water where crops are irrigated with water from the rivers contaminated with heavy metals. The central region of Peru is an important agricultural production area irrigated with the water from the Mantaro River that contains high concentrations of toxic metals. In this sense, this study aims to analyze the content of heavy metals and arsenic in the soil and in cereal grains and to evaluate the possible human risk in the central region of Peru.

\section{MATERIAL AND METHODS}

\section{Study area}

The Mantaro river watershed is located in the Central Andes of Peru, between $10^{\circ} 30^{\prime}$ to $13^{\circ}$ $30^{\prime}$ 'South Latitude and between $74^{\circ} 00^{\prime}$ to $76^{\circ} 30^{\prime}$ West Longitude. The Mantaro river is the main river of the basin, its flow depends on rainfall, the level of Lake Junin and the lakes located at the foot of the snow-capped mountains of the western cordillera and the snow-capped mountains of Huaytapallana. The tributaries of the Mantaro river run through many of the mining areas in the basin (Geophysical Institute of Peru, 2010). Along its course, the Mantaro River is the recipient of wastewater from many of the mining and urban industries of central Peru. Throughout the valley, during the dry season, the polluted waters of the Mantaro river are used for irrigation of large agricultural areas of importance to the Peru's economy. The agricultural area with the main food crops, such as potatoes, barley, corn and wheat is $56,314.00 \mathrm{ha}$. In the highlands of the Junín region, $74.9 \%$ of the agricultural surface is dry land, while $25.1 \%$ is irrigated (Agriculture Ministry, 2008). The sampling sites were defined in seven agricultural zones in the province of 
Concepción in the Junín region that are irrigated with the contaminated water from the Mantaro River (National Water Authority, 2014).

\section{Collection of soil samples and food grains}

The sampling was carried out in four agricultural zones with maize cultivation and three zones with wheat cultivation, during May and June 2019. There were 168 samples of corn soil and grains consisted of 168 as well as 126 samples of barley soil and grains. Seven samples of approximately $100 \mathrm{~g}$ of surface soil were collected in each sampling area using a $20 \mathrm{~cm}$ deep stainless steel drill type device. The soil samples from each zone were mixed to obtain a composite sample of approximately $500 \mathrm{~g}$. The corn and barley grain samples were collected from the same soil sampling sites in the respective agricultural zones prior to harvest. The samples were placed in zipper plastic bags, labeled and then transferred to the laboratory.

The soil samples were air dried at room temperature, disaggregated and sieved through a $2 \mathrm{~mm}$ stainless steel mesh screen to remove stones and plant debris. The sieved soil was placed in an electric oven at $60^{\circ} \mathrm{C}$ for 24 hours and the completely dried samples were crushed in a mortar. The resulting soil was stored in $250 \mathrm{ml}$ HDPE bottles until further analysis. The food grains were dried for 10 days, then husked and placed in an oven at $100^{\circ} \mathrm{C}$ for $6 \mathrm{~h}$. The dried samples were ground using a stainless steel mill and transferred to high density polyethylene (HDPE) containers for the heavy metal and metalloid analysis.

\section{Digestion and analytical procedures}

The soil samples $(1 \mathrm{~g})$ were placed in a beaker with $10 \mathrm{ml} \mathrm{HNO}_{3}$ and $5 \mathrm{ml} \mathrm{H}_{2} \mathrm{SO}_{4}$ concentrate. The beakers were then heated to $100^{\circ} \mathrm{C}$ in the microwave digestion system until almost all the nitrogen dioxide was evaporated. A blank was also prepared for each digestion batch using $10 \mathrm{ml} \mathrm{HNO}_{3}$ and $5 \mathrm{ml}$ of concentrated $\mathrm{H}_{2} \mathrm{SO}_{4}$ to check its homogeneity and processing efficiency. The digested samples were then cooled and filtered through acid-treated Millipore filters $(0.45 \mathrm{~mm}$ mesh). They were transferred into graduated test tubes and deionized water was added up to the $50 \mathrm{ml}$ mark. The digested 50-ml filter solution was transferred to an acid-rinsed polyethylene sample container with a label for analysis (USEPA, 1996). The food grains $(1 \mathrm{~g})$ were digested with $10 \mathrm{ml}$ of concentrated $\mathrm{HNO}_{3}$ for $1 \mathrm{~h}$ at $80^{\circ} \mathrm{C}$ and then for $20 \mathrm{~h}$ at $120^{\circ} \mathrm{C}$ (Khan et al., 2019). The digested samples were filtered in $50 \mathrm{ml}$ graduated plastic tubes and the final volume was adjusted

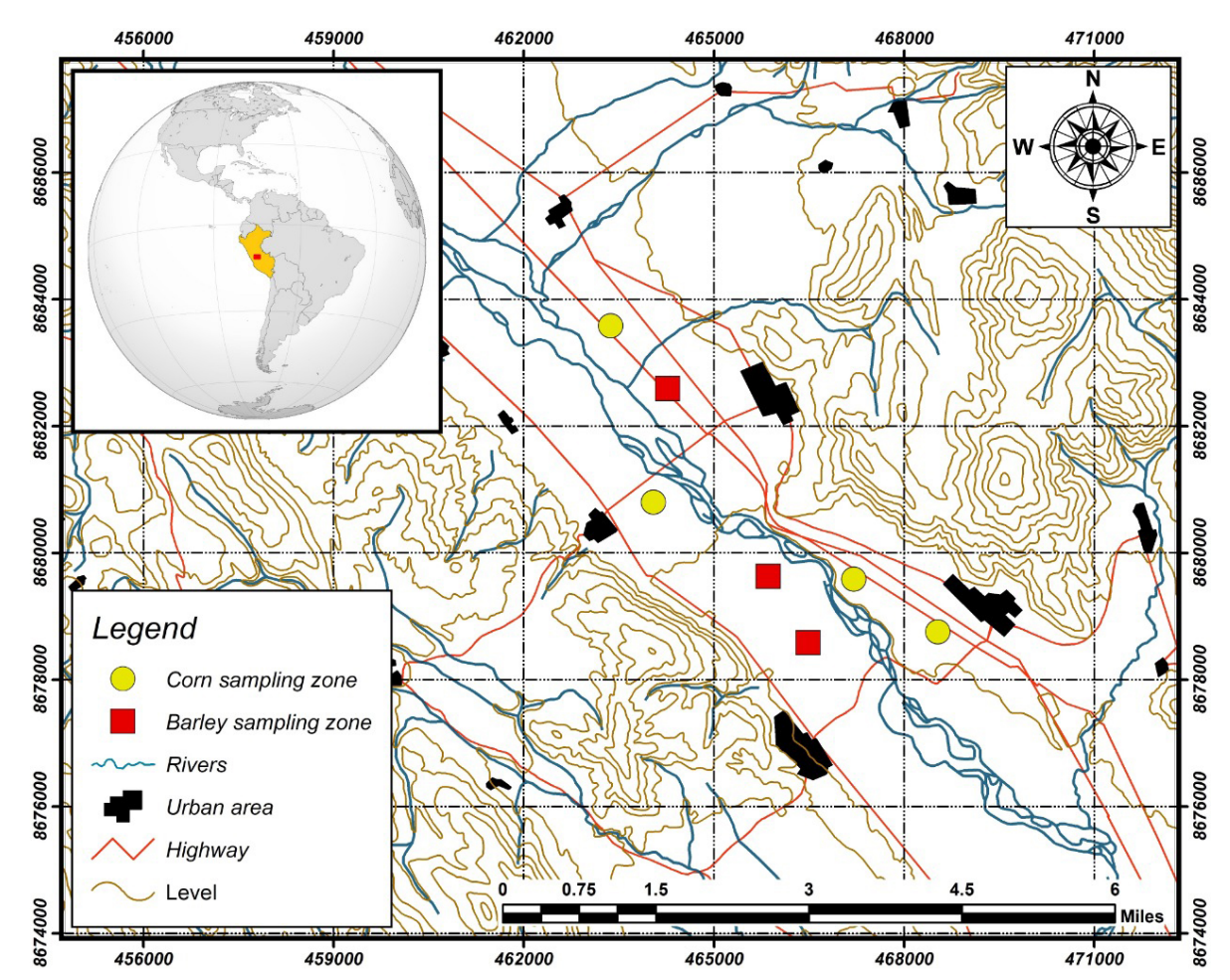

Figure 1. Map of location of sampling zones in the province of Concepción, Peru 
to $50 \mathrm{ml}$ with deionized water. The analysis of heavy metals and arsenic was performed by flame atomic absorption spectrophotometry. All samples were analyzed in triplicate.

\section{Quality control and assurance}

Quality control was performed through the application of standard laboratory and quality control protocols that included replication, the use of national and international standards for each metal investigated, and the determination of the accuracy of the instrument (APHA, 2012). The glassware was thoroughly cleaned with detergent and rinsed several times with deionized water before use. Standard solutions of $100 \mathrm{mg} / \mathrm{L}$ concentration for heavy metals and As were prepared from the $1000 \mathrm{mg} / \mathrm{L}$ standard. Then, working standards were prepared with $1 \%$ nitric acid.

\section{Statistical analysis}

A permutational multivariate variance analysis (PERMANOVA) was performed to test the effect of type of crop and sampling sector on the $\mathrm{Pb}, \mathrm{Cu}, \mathrm{Fe}, \mathrm{Zn}$ and $\mathrm{As}$ concentrations in crop soil and corn and barley grains, using the Adonis function in the vegan R-package. The heavy metal and As concentrations in crop and grain soils were further explored by principal component analysis (PCA). VARIMAX rotation was performed to improve the interpretability of uncorrelated components (Gottfried et al., 2009). All significant loads (i.e. loads $>0.45$ ) were included in the interpretation of the main components (PC). Spearman's correlation coefficient (rho) was used as correlation measure (dependence) between soil and grain variables, giving a value between +1 and -1 , where 1 represents the total positive correlation, 0 means no correlation and -1 represents the total negative correlation. The rho coefficient is based on the ranges of the observations; Spearman's range correlation coefficient does not assume that the relationship between variables is linear.

\section{Human health risk assessment}

\section{Exposure doses}

The Mantaro Valley population are potential receptors of pollution; as agricultural areas are interspersed with peri-urban areas. Considering that agriculture is the main activity of the Andean population, the subjects were divided into three groups: adults, farmers or shepherds and children. The exposure to soil contamination can occur through the ingestion of soil, dermal contact and inhalation (USEPA, 2011). The risk of exposure to heavy metals and arsenic in soil was assessed using equations (1), (2) and (3).

$$
D_{\text {ing }}=\left(\frac{C_{s} \times \operatorname{IngR} \times E F \times E D}{B W \times A T}\right) \times 10^{-6}
$$

where: $D_{\text {ing }}$ is the dose of exposure by ingestion of the element from soil ( $\mathrm{mg} \mathrm{kg}^{-1}$ body weight-day);

Cs is the concentration of the element in soil $\left(\mathrm{mg} \mathrm{kg}^{-1}\right)$;

IngR is the rate of soil ingestion (100 mg day ${ }^{-1}$ for adults, $330 \mathrm{mg}$ day $^{-1}$ for adult farmers or herders and $200 \mathrm{mg}$ day $^{-1}$ for children);

$E F$ is the frequency of exposure (350 days per year ${ }^{-1}$ );

$E D$ is the duration of the exposure to noncarcinogenic (30 years for adults and 6 years for children) and carcinogenic contaminants (24 years for adults and 6 years for children);

$B W$ is the average body weight of the exposed person (70 kg for adults and $15 \mathrm{~kg}$ for children).

$A T$ is the average time of exposure $(10,950$ days for adults and 2,190 days for children).

$$
D_{\text {der }}=\left(\frac{C_{s} \times S A \times S L \times A B S \times E F \times E D}{B W \times A T}\right) \times 10^{-6}
$$

where: $D_{d e r}$ is the dose of exposure through the dermal absorption of the element from soil ( $\mathrm{mg} \mathrm{kg}^{-1}$ body weight-day);

$C s$ is the concentration of the element in the soil $\left(\mathrm{mg} \mathrm{kg}^{-1}\right)$;

$S A$ is the surface area of exposed skin $\left(5,700 \mathrm{~cm}^{2}\right.$ for adults; $3,300 \mathrm{~cm}^{2}$ for farmers or herders and $2,800 \mathrm{~cm}^{2}$ for children); $S L$ is the factor of adherence of the soil to the skin $\left(0.07 \mathrm{mg} \mathrm{cm}^{-2}\right.$ day $^{-1}$ for adults, $0.3 \mathrm{mg} \mathrm{cm}^{-2}$ day $^{-1}$ for farmers or herders, and $0.2 \mathrm{mg} \mathrm{cm}^{-2}$ day $^{-1}$ for children), $A B S$ is the dermal absorption factor ( 0.03 for As and 0.001 for other elements), $E F, E D, B W$, and $A T$ as detailed in equation (1) (EPA, 2004). 


$$
D_{\text {inh }}=\frac{C_{s} \times \operatorname{inhR} \times E F \times E D}{P E F \times B W \times A T}
$$

where: $D_{i n h}$ is the dose of exposure through the inhalation of the element from soil ( $\mathrm{mg} \mathrm{kg}^{-1}$ body weight-day);

Cs is the concentration of the element in soil $\left(\mathrm{mg} \mathrm{kg}^{-1}\right)$;

InhR is the inhalation rate from soil (20 mg day ${ }^{-1}$ for adults and $7.6 \mathrm{mg}$ day $^{-1}$ for children).

$P E F$ is the particulate emission factor (1.36 x 109). EF, ED, BW and AT are detailed in equation (1).

\section{Non-carcinogenic risk assessment}

The non-carcinogenic risk has been evaluated using the hazard ratio (HQ), which was calculated by dividing the exposure value by the reference dose (Antoniadis et al., 2019).

$$
H Q_{\text {ing } / \mathrm{inh} / \mathrm{der}}=D_{\text {ing } / \mathrm{inh} / \mathrm{der}} / \mathrm{Rf} D_{\text {ing } / \mathrm{inh} / \mathrm{der}}
$$

where: $H Q_{\text {ing/inh/der }}$ is the hazard quotient for ingestion, inhalation and dermal contact.

$R f D_{\text {ing/inh/der }}$ is the reference dose for ingestion, dermal contact or inhalation (mg $\mathrm{kg}^{-1}$ body weight day-1), which is the threshold value for the toxicity of each element obtained from the literature (Haidong et al., 2017).

If the $\mathrm{HQ} \leq 1$ means that detrimental health effects are unlikely. HQ $>1$ reveals likely detrimental health effects. HQ $>10$ indicates high chronic risk. The calculated HQs were integrated and expressed as a hazard index (HI) (Al-bagawi, 2019)

$$
\mathrm{HI}=\sum_{i=1}^{n} \mathrm{HQ}_{\text {ing } / \text { inh } / \mathrm{der}}
$$

where: $\mathrm{HI}_{\text {ing/inh/der }}$ is the total chronic hazard index for each route of exposure. " $n$ " is the total number of chemicals.

If $\mathrm{HI}<1$, it is assumed that the non-cancer adverse effect due to a given exposure pathway or chemical is negligible, while the potential for chronic effects may be a concern when $\mathrm{HI}>1$.

\section{Carcinogenic risk assessment}

The carcinogenic risk was evaluated considering the USEPA risk assessment guide (EPA,
2004). The chronic daily intake (CDI) was calculated with the equation (6).

$$
\mathrm{CDI}_{\text {ing }}=\mathrm{C}_{\mathrm{s}} \times \mathrm{DI} / \mathrm{BW}
$$

where: $C_{s^{\prime}} D I$ and $B W$ represent the concentration of trace metal in soil in $\left(\mathrm{mg} \mathrm{kg}^{-1}\right)$, mean daily soil intake and body weight, respectively.

Cancer risk (CR) was calculated using the formula:

$$
\mathrm{CR}_{\text {ing }}=\mathrm{CDI}_{\text {ing }} / \mathrm{SF}_{\text {ing }}
$$

where: $S F_{\text {ing }}$ is the cancer slop factor.

$S F_{\text {ing }}^{\text {ing }}$ As is $1.5 \mathrm{mg} \mathrm{kg}^{-1}$ day $^{-1}$ (Kamunda et al., 2016).

If risk $>1.0 \times 10^{-4}$ is considered unacceptable; $1.0 \times 10^{-4}<$ risk $<1.0 \times 10^{-6}$ is considered an acceptable range; risk $<1.0 \times 10^{-6}$ is considered as no significant health effects.

\section{Human health risk from heavy metals in cultivated grains}

The bioconcentration factor (BCF) was calculated using equation (8).

$$
B C F=\frac{C_{\text {grain }}}{C_{\text {soil }}}
$$

where: $C_{\text {grain }}$ and $C_{\text {soil }}$ are the total concentrations of a given heavy metal and metalloid in the grain and soil of the crop $\left(\mathrm{mg} \mathrm{kg}^{-1}\right)$, respectively.

The potential human risk of exposure to heavy metals and metalloids from the consumption of cultivated grains was evaluated using THQ (EPA, 2000).

If THQ $>1$, the ratio reveals a potential health risk associated with the contaminant. If $\mathrm{THQ}<1$, there is no potential health risk associated with the contaminant. In order to evaluate the carcinogenic risk of heavy metals and metalloids in cultivated grains, only the risk of ingestion was considered, and was calculated using the following equations (9) and (10).

$$
\begin{gathered}
T H Q=\frac{\mathrm{EDI}}{R f D_{\text {ing }}}=\frac{\mathrm{EF} \times \mathrm{ED} \times \mathrm{IngR} \times \mathrm{C}}{R f D_{\text {ing }} \times B W \times A T_{n c}} \times 10^{3} \\
\mathrm{CR}_{\text {ing }}=\mathrm{EDI} \times \mathrm{SF}_{\text {ing }}
\end{gathered}
$$

where: $E D I$ is the estimated daily intake of each heavy metal and metalloid and IngR $=402 \mathrm{~g} \mathrm{~d}^{-1}$. 


\section{RESULTS}

\section{Analysis of heavy metals and arsenic in soil and grains from the Concepción province}

Table 1 shows the mean concentration and standard deviation of heavy metals and arsenic determined in the soil and grain samples from the corn and barley crops in the province of Concepción in central Peru. The overall data showed that the mean concentration of heavy metals and arsenic varied by sampling site and type of crop. The decreasing order of average concentrations of heavy metals and metalloid in the soil samples of corn and barley crops was: $\mathrm{Fe}>\mathrm{Zn}>\mathrm{Pb}$ $>\mathrm{Cu}>\mathrm{As}$. In corn crop soil, the highest mean concentration of $\mathrm{Fe}\left(29733.72 \mathrm{mg} \mathrm{kg}^{-1}\right)$ was recorded in Sc4, Zn (1164.89 $\mathrm{mg} \mathrm{kg}^{-1}$ ) in $\mathrm{Sc} 3, \mathrm{~Pb}$ (96.49 $\left.\mathrm{mg} \mathrm{kg}^{-1}\right)$ in $\mathrm{Sc} 2, \mathrm{Cu}\left(70.80 \mathrm{mg} \mathrm{kg}^{-1}\right)$ in $\mathrm{Sc} 3$ and $\mathrm{As}\left(12.66 \mathrm{mg} \mathrm{kg}^{-1}\right)$ in Sc1. In the barley soils, the highest mean concentration of $\mathrm{Fe}$ (29400.36 $\mathrm{mg} \mathrm{kg}^{-1}$ ) was recorded in Sb1, $\mathrm{Zn}$ (1414.06 $\left.\mathrm{mg} \mathrm{kg}^{-1}\right)$ in $\mathrm{Sb} 1, \mathrm{~Pb}\left(185.31 \mathrm{mg} \mathrm{kg}^{-}\right.$ $\left.{ }^{1}\right)$ in $\mathrm{Sb3}, \mathrm{Cu}\left(78.48 \mathrm{mg} \mathrm{kg}^{-1}\right)$ in $\mathrm{Sb} 1$ and $\mathrm{As}$ (9.36 $\left.\mathrm{mg} \mathrm{kg}^{-1}\right)$ in Sb1.

The concentrations of $\mathrm{Fe}$ and As in the corn soils were higher than the concentrations of these elements in the barley soils. Similar behaviors were found in the $\mathrm{Cu}, \mathrm{Pb}$ and $\mathrm{Zn}$ concentrations in the barley soils compared to the concentrations of these elements in the corn soils. The crop soils located in the northern Mantaro River valley ( $\mathrm{Sc} 1$ and $\mathrm{Sc} 2$ ) showed higher mean $\mathrm{As}$ and $\mathrm{Pb}$ concentrations, respectively, and a high standard deviation compared to the other corn sampling sites. The barley soils with higher mean $\mathrm{As}$ and $\mathrm{Pb}$ concentrations were also located in the north of the valley ( $\mathrm{Sb} 1) . \mathrm{Fe}, \mathrm{Cu}$ and $\mathrm{Zn}$ in the corn and barley soils showed no significant differences between their mean concentrations.

$\mathrm{Pb}$ is the only element that exceeds the environmental quality standards for soils in Peru (70 $\mathrm{mg} \mathrm{kg}^{-1}$ ) (Ministry of the Environment, 2017) and threshold values of the Food and Agriculture Organization of the United Nations (FAO) and the World Health Organization (WHO) (100 $\mathrm{mg} \mathrm{kg}^{-1}$ ) (FAO/WHO, 1993), with the sampling sites located south of the valley having the highest concentrations of $\mathrm{Pb}\left(185.31 \mathrm{mg} \mathrm{kg}^{-1}\right)$. However, the average concentrations of $\mathrm{Cu}, \mathrm{Pb}, \mathrm{Zn}$ and $\mathrm{As}$ in the soils of both types of crops did not exceed the threshold values of the United States Department of Agriculture (USDA) (4300, 420, 7500 and $75 \mathrm{mg} \mathrm{kg}^{-1} ; \mathrm{Cu}, \mathrm{Pb}, \mathrm{Zn}$ and As, respectively)

Table 1. Mean concentration and standard deviation of heavy metals and arsenic in soils and grains of the Concepción province and safety limit values, expressed in $\mathrm{mg} \mathrm{kg} \mathrm{g}^{-1}$

\begin{tabular}{|c|c|c|c|c|c|c|c|c|c|c|c|c|c|c|c|c|}
\hline \multirow{2}{*}{ Sample } & \multirow{2}{*}{$\begin{array}{c}\text { Sampling } \\
\text { zone } \\
\end{array}$} & \multicolumn{3}{|c|}{$\mathrm{Cu}$} & \multicolumn{3}{|c|}{$\mathrm{Pb}$} & \multicolumn{3}{|c|}{$\mathrm{Zn}$} & \multicolumn{3}{|c|}{$\mathrm{Fe}$} & \multicolumn{3}{|c|}{ As } \\
\hline & & \multicolumn{3}{|c|}{ Mean \pm SD } & \multicolumn{3}{|c|}{ Mean \pm SD } & \multicolumn{3}{|c|}{ Mean \pm SD } & \multicolumn{3}{|c|}{ Mean \pm SD } & \multicolumn{3}{|c|}{ Mean \pm SD } \\
\hline \multirow{4}{*}{ Soil corn } & Sc1 & 63.45 & \pm & 2.59 & 88.49 & \pm & 1.32 & 1079.70 & \pm & 36.93 & 27589.16 & \pm & 723.31 & 12.66 & \pm & 1.95 \\
\hline & Sc2 & 56.18 & \pm & 4.96 & 96.49 & \pm & 3.80 & 1026.50 & \pm & 25.25 & 28427.42 & \pm & 806.66 & 11.18 & \pm & 0.31 \\
\hline & Sc3 & 70.80 & \pm & 4.86 & 88.09 & \pm & 2.31 & 1164.89 & \pm & 83.33 & 28507.36 & \pm & 1343.16 & 10.57 & \pm & 0.10 \\
\hline & Sc4 & 59.15 & \pm & 3.03 & 93.50 & \pm & 5.59 & 1164.16 & \pm & 89.97 & 29733.72 & \pm & 574.58 & 10.65 & \pm & 1.14 \\
\hline \multirow{3}{*}{$\begin{array}{c}\text { Soil } \\
\text { barley }\end{array}$} & Sb1 & 78.48 & \pm & 1.0113 & 154.95 & \pm & 27.59 & 1414.06 & \pm & 90.45 & 29400.36 & \pm & 1372.40 & 9.36 & \pm & 0.76 \\
\hline & $\mathrm{Sb} 2$ & 77.48 & \pm & 1.7125 & 151.05 & \pm & 6.33 & 1296.69 & \pm & 53.28 & 28796.21 & \pm & 851.59 & 9.32 & \pm & 0.44 \\
\hline & Sb3 & 77.67 & \pm & 2.0615 & 185.31 & \pm & 18.38 & 1345.34 & \pm & 99.47 & 27852.47 & \pm & 617.99 & 9.16 & \pm & 0.49 \\
\hline \multicolumn{17}{|c|}{ Safety limits } \\
\hline \multicolumn{2}{|l|}{ USDA } & \multicolumn{3}{|c|}{4300} & \multicolumn{3}{|c|}{420} & \multicolumn{3}{|c|}{7500} & & & & \multicolumn{3}{|c|}{75} \\
\hline \multicolumn{2}{|l|}{ FAO/WHO } & \multicolumn{3}{|c|}{100} & \multicolumn{3}{|c|}{100} & & & & & & & \multicolumn{3}{|c|}{20} \\
\hline \multicolumn{2}{|c|}{ EQS soil Peru } & & & & \multicolumn{3}{|c|}{70} & & & & & & & \multicolumn{3}{|c|}{50} \\
\hline \multirow{4}{*}{$\begin{array}{l}\text { Grain } \\
\text { corn }\end{array}$} & Gc1 & 2.18 & \pm & 0.12 & \multicolumn{3}{|c|}{ nd } & 29.00 & \pm & 4.78 & 137.08 & \pm & 4.87 & 0.070 & \pm & 0.008 \\
\hline & Gc2 & 2.04 & \pm & 0.09 & & nd & & 32.35 & \pm & 3.64 & 146.75 & \pm & 2.75 & 0.083 & \pm & 0.009 \\
\hline & Gc3 & 2.21 & \pm & 0.09 & & nd & & 40.88 & \pm & 1.41 & 205.64 & \pm & 5.10 & 0.061 & \pm & 0.004 \\
\hline & Gc4 & 2.05 & \pm & 0.09 & & nd & & 45.22 & \pm & 3.01 & 207.31 & \pm & 13.29 & 0.100 & \pm & 0.015 \\
\hline & Gb1 & 18.71 & \pm & 0.85 & & nd & & 58.85 & \pm & 1.23 & 69.70 & \pm & 7.84 & 0.124 & \pm & 0.022 \\
\hline $\begin{array}{l}\text { Grain } \\
\text { barley }\end{array}$ & $\mathrm{Gb} 2$ & 19.97 & \pm & 1.09 & & nd & & 56.16 & \pm & 1.12 & 69.99 & \pm & 9.38 & 0.142 & \pm & 0.003 \\
\hline & Gb3 & 17.41 & \pm & 0.81 & & nd & & 65.58 & \pm & 0.96 & 72.97 & \pm & 7.91 & 0.142 & \pm & 0.016 \\
\hline Safety limi & & & & & & & & & & & & & & & & \\
\hline $\mathrm{FAO} / \mathrm{WHO}$ & & & 5 & & & 5 & & & & & & & & & & \\
\hline EPA & & & 1 & & & 0.2 & & & & & & & & & 0.1 & \\
\hline
\end{tabular}


(USDA, 2000) nor the maximum permissible values of $\mathrm{Cu}$ and $\mathrm{As}$ in soils of FAO and WHO (FAO/ WHO, 2011) (100 y $20 \mathrm{mg} \mathrm{kg}^{-1}$, respectively).

The decreasing order of the maximum mean concentration of heavy metals and As in corn and barley grains was: $\mathrm{Fe}$ (207.31 $\mathrm{mg} \mathrm{\textrm {kg } ^ { - 1 }}$ in corn and, $72.97 \mathrm{mg} \mathrm{kg}^{-1}$ in barley) $>$ Zinc (45.22 $\mathrm{mg} \mathrm{kg}^{-1}$ in corn and $65.58 \mathrm{mg} \mathrm{kg}^{-1}$ in barley) $>\mathrm{Cu}\left(2.21 \mathrm{mg} \mathrm{kg}^{-1}\right.$ in corn to $19.97 \mathrm{mg} \mathrm{kg}^{-1}$ in barley) $>$ As $\left(0.100 \mathrm{mg} \mathrm{kg}^{-1}\right.$ in corn to $0.142 \mathrm{mg} \mathrm{kg}^{-1}$ in barley). The results of this study also revealed that the type of crop has a significant influence on the concentrations; since barley grain had a higher concentration of these heavy metals and metalloids compared to corn. In addition, it was found that the sampling sites located in the southern part of the Mantaro Valley are characterized by corn grain production with higher concentrations of $\mathrm{Fe}$ compared to the northern sectors $(\mathrm{p}<0.05)$. This is the only element in corn grain that has mean concentrations higher than the mean concentrations of barley grains.

The mean concentrations of $\mathrm{Cu}, \mathrm{Zn}$ and $\mathrm{As}$ in barley grains were significantly higher than the mean concentrations of these heavy metals and metalloids in corn grains. The $\mathrm{Zn}$ concentrations changed significantly $(p<0.05)$ due to the effect of the sampling site on corn grains. The sampling sites located in the southern part of the Mantaro valley have higher concentrations of $\mathrm{Zn}$ in the grain than the other two sites evaluated. The mean $\mathrm{Cu}$ concentrations exceeded the safety limits of FAO (5.0 $\left.\mathrm{mg} \mathrm{kg}^{-1}\right)$ and the U.S. Environmental Protection Agency (1.0 mg kg-1 $)$ [37]. In contrast, mean As concentrations in grains from these cereals did not exceed the EPA limits (0.15 $\left.\mathrm{mg} \mathrm{kg}^{-1}\right)$.

Permutational multivariate variance analysis (PERMANOVA) showed that the effect of the type of crop and the sampling zone influence the concentrations of $\mathrm{Pb}, \mathrm{Cu}, \mathrm{Fe}, \mathrm{Zn}$ and $\mathrm{As}$ in soil and grains significantly $(p<0.05)$. However, the concentrations of these toxic elements in the barley cultivation soils in the northern, central and southern sampling zones did not show significant differences $(p>0.05)$. In contrast, the concentrations of heavy metals and As in the corn growing soil showed significant differences due to the effect of the sampling zone (Table 2).

The result of the principal component analysis (PCA) for heavy metals and As in the soil samples from corn and barley crops showed that the first two principal components represented $81.03 \%$ of the total variance in the data set. The first major component (PC1) represented 58.57\% of the total variance. The $\mathrm{Cu}, \mathrm{Pb}$ and $\mathrm{Zn}$ concentrations showed high positive charges $(0.75$ to 0.95 ) and the As concentrations showed high negative charges $(-0.75$ to -0.95$)$ at the PC1. The $\mathrm{Fe}$ concentrations showed high positive charges ( 0.70 to 0.91$)$ at PC2. The crop soils with higher concentrations of $\mathrm{Zn}, \mathrm{Cu}$ and $\mathrm{Pb}$ corresponded to the zones with barley crops and soils with higher concentrations of As to the zones with corn crops. The small differences with significant trend from one agricultural area to another are explained by $\mathrm{PC} 2$. The Fe concentrations determined the difference between geographically distributed agricultural zones. In the case of barley soils, the northern zones of the Mantaro River valley showed

Table 2. Permutational multivariate variance analysis of crop sectors according to the metal and metalloid concentration in soils and grains

\begin{tabular}{|c|c|c|c|c|c|c|c|c|}
\hline Sample & Sampling zone & Gc4 & Gc3 & Gc2 & Gc1 & Gb3 & $\mathrm{Gb} 2$ & Gb1 \\
\hline \multirow{7}{*}{ Soil } & Gc4 & & & & & & & \\
\hline & Gc3 & 0.0071 & & & & & & \\
\hline & Gc2 & 0.0086 & 0.0081 & & & & & \\
\hline & Gc1 & 0.0254 & 0.0685 & 0.0845 & & & & \\
\hline & Gb3 & 0.0084 & 0.0093 & 0.0088 & 0.0077 & & & \\
\hline & $\mathrm{Gb} 2$ & 0.0081 & 0.0067 & 0.0084 & 0.0085 & 0.0581 & & \\
\hline & Gb1 & 0.0066 & 0.0072 & 0.008 & 0.007 & 0.0888 & 0.2554 & \\
\hline \multirow{7}{*}{ Grain } & Gc4 & & & & & & & \\
\hline & Gc3 & 0.0079 & & & & & & \\
\hline & Gc2 & 0.0082 & 0.0093 & & & & & \\
\hline & Gc1 & 0.0076 & 0.0075 & 0.0636 & & & & \\
\hline & Gb3 & 0.0092 & 0.0069 & 0.0098 & 0.0069 & & & \\
\hline & $\mathrm{Gb} 2$ & 0.0066 & 0.0086 & 0.0073 & 0.0089 & 0.0067 & & \\
\hline & Gb1 & 0.01 & 0.0078 & 0.0081 & 0.0084 & 0.0676 & 0.1206 & \\
\hline
\end{tabular}


higher concentrations of Fe. The corn soils from the zones located in the southern part of this valley showed higher Fe concentrations (Figure 2).

PCA of heavy metals and arsenic in barley and corn grains showed that the first two main components represented $94.77 \%$ of the total variance in the data set. $\mathrm{PC} 1$ represented $85.75 \%$ of the total variance. The $\mathrm{Cu}, \mathrm{Zn}$ and As concentrations showed high positive charges ( 0.75 to 0.95 ) and the $\mathrm{Fe}$ concentrations showed high negative charges $(-0.75$ to -0.95$)$ in PC1. Barley grains showed higher concentrations of $\mathrm{Zn}, \mathrm{As}$ and $\mathrm{Cu}$ compared to the corn grains with higher Fe concentration. No significant effects were observed due to the geographical location of the agricultural areas. However, the concentrations of some toxic elements in the grains of certain areas were slightly higher. Barley grains from the areas located south of the Mantaro River Valley had higher concentrations of $\mathrm{Zn}$, As and $\mathrm{Cu}$ compared to the concentrations of these elements in the grains of this cereal in the agricultural areas located in the north of the valley. Corn grains from the areas located in the southern part of the valley showed higher concentrations of $\mathrm{Zn}$ than the areas located in the northern part of the valley, with a tendency to have a higher concentration of $\mathrm{Fe}$ of the same equivalence (Figure 3 ).

Spearman correlation coefficients between heavy metals and arsenic in the corn crop soils showed that $\mathrm{Cu}$ and $\mathrm{Pb}$ indicated a significant negative correlation $(-0.43$ a -0.71$)$ with reflectance spectra at a significance level of 0.01 . In turn, As and $\mathrm{Zn}$ showed significant positive

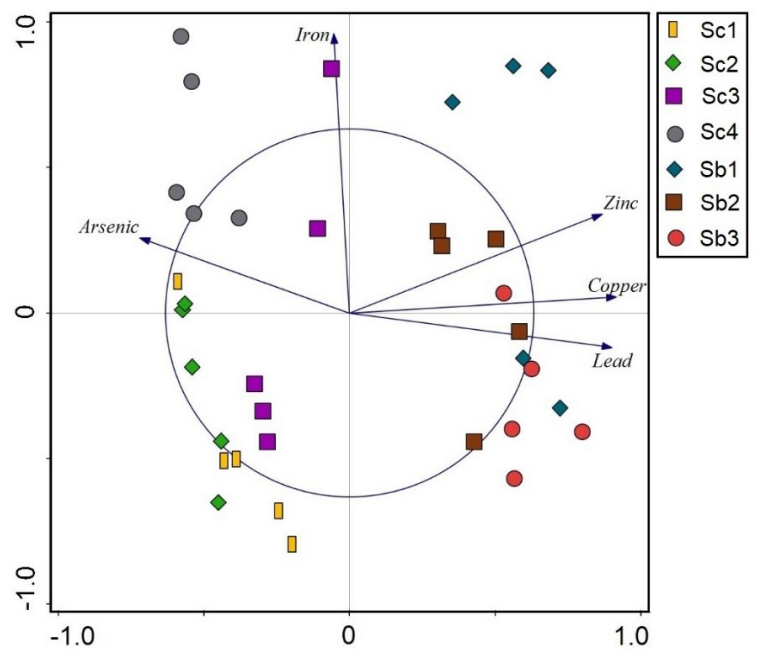

Figure 2. Perceptual map f principal component analysis for metals and metalloids in corn and barley soils correlation (0.43 to 0.71$)$. In the soils with barley crops it was found that $\mathrm{Zn}$ and $\mathrm{Cu}$ showed positive significant correlation ( 0.43 to 0.71$)$ and, $\mathrm{Fe}$ and $\mathrm{Pb}-$ negative significant correlation $(-0.43$ a -0.71). In corn grains it was found that As and $\mathrm{Cu}$ revealed negative significant correlation $(-0.43$ a -0.71$)$ and, $\mathrm{Fe}$ and $\mathrm{Zn}$ highly positive significant correlation ( 0.71 to 0.9 ). Barley grains only revealed significant negative correlation between $\mathrm{Zn}$ and $\mathrm{Cu}$.

\section{Health risk assessment for exposure to heavy metals and arsenic from soil and cereal grains}

The results revealed that the concentrations of heavy metals and As in corn and barley soil did not exceed the environmental quality standards (EQS) for soil in Peru (Ministry of the Environment, 2017) and the international threshold values (USDA, 2000); (FAO/WHO, 1993) except for $\mathrm{Pb}$, the mean concentrations of which exceeded the EQS for Peru and the FAO/WHO threshold values. However, due to their toxicological effect and the carcinogenic nature of some of them, the risk they pose to the health of children, adults and farmers was determined. As was the only carcinogenic element detected in the soil and grains of the cereals under study. Therefore, both the carcinogenic and non-carcinogenic risks of this metalloid were determined through equations (1) to (8) (USEPA, 2011; Zhao et al., 2014) (Table 3). The non-carcinogenic risk of $\mathrm{Pb}$ and $\mathrm{As}$ was determined by the hazard quotient (HQ) and the hazard index (HI).

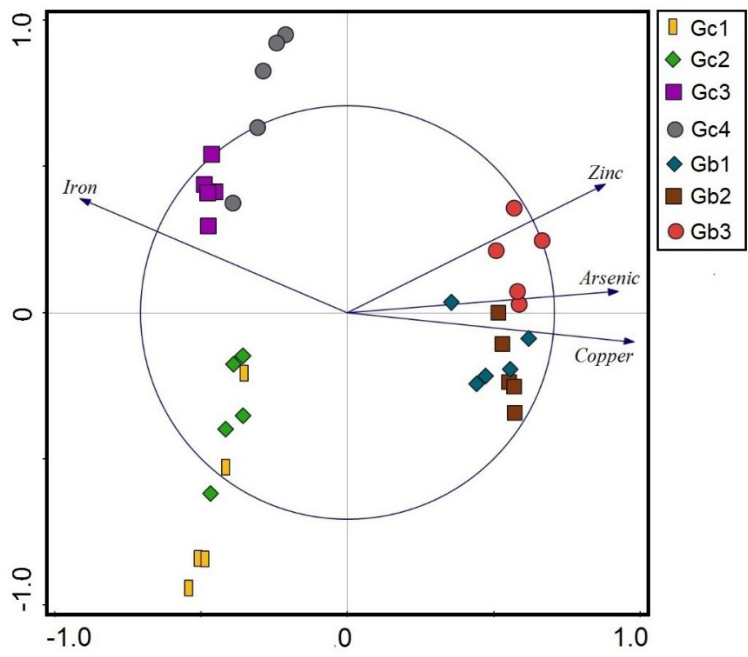

Figure 3. Perceptual map of principal component analysis for metals and metalloids in corn and barley grains 
Table 3. Non-carcinogenic risks to humans from soil lead and arsenic

\begin{tabular}{|c|c|c|c|c|c|c|c|c|c|c|c|c|}
\hline \multirow{2}{*}{$\begin{array}{l}\text { Ele- } \\
\text { ment }\end{array}$} & \multirow{2}{*}{$\begin{array}{c}\text { Sampling } \\
\text { zones }\end{array}$} & \multirow{2}{*}{$\begin{array}{l}\mathrm{C}_{\mathrm{CUL}} \\
\mathrm{mg} \\
\mathrm{kg}^{-1}\end{array}$} & \multirow{2}{*}{$\begin{array}{l}\text { Pathways } \\
\text { exposure }\end{array}$} & \multicolumn{3}{|c|}{ CDI } & \multicolumn{3}{|c|}{$\mathrm{HQ}$} & \multicolumn{3}{|c|}{$\mathrm{HI}$} \\
\hline & & & & Children & Adult & Farmer & Children & Adult & Farmer & Children & Adult & Farmer \\
\hline \multirow{21}{*}{$\mathrm{Pb}$} & \multirow{3}{*}{ Sc1 } & \multirow{3}{*}{92.68} & Ingestion & $\begin{array}{c}1.18 \times \\
10^{-3}\end{array}$ & $\begin{array}{c}1.02 \times \\
10^{-4}\end{array}$ & $\begin{array}{c}3.35 \times \\
10^{-4}\end{array}$ & $\begin{array}{c}3.39 \times \\
10^{-1}\end{array}$ & $\begin{array}{c}2.90 \times \\
10^{-2}\end{array}$ & $\begin{array}{c}9.58 \times \\
10^{-2}\end{array}$ & \multirow{3}{*}{$\begin{array}{c}9.02 \times \\
10^{-1}\end{array}$} & \multirow{3}{*}{$\begin{array}{c}7.69 \times \\
10^{-2}\end{array}$} & \multirow{3}{*}{$\begin{array}{c}2.35 \times \\
10^{-1}\end{array}$} \\
\hline & & & Inhalation & $\begin{array}{c}6.53 \times \\
10^{-8}\end{array}$ & $\begin{array}{c}5.23 \times \\
10^{-8}\end{array}$ & $\begin{array}{c}5.23 \times \\
10^{-8}\end{array}$ & $\begin{array}{c}4.27 \times \\
10^{-2}\end{array}$ & $\begin{array}{c}3.47 \times \\
10^{-3}\end{array}$ & $\begin{array}{c}3.47 \times \\
10^{-3}\end{array}$ & & & \\
\hline & & & Dermal & $\begin{array}{c}1.49 \times \\
10^{-4}\end{array}$ & $\begin{array}{c}1.22 \times \\
10^{-5}\end{array}$ & $\begin{array}{c}1.22 \times \\
10^{-5}\end{array}$ & $\begin{array}{c}1.87 \times \\
10^{-5}\end{array}$ & $\begin{array}{c}1.49 \times \\
10^{-5}\end{array}$ & $\begin{array}{c}1.49 \times \\
10^{-5}\end{array}$ & & & \\
\hline & \multirow{3}{*}{ Sc2 } & \multirow{3}{*}{108.36} & Ingestion & $\begin{array}{c}1.39 \times \\
10^{-3}\end{array}$ & $\begin{array}{c}1.19 \times \\
10^{-4}\end{array}$ & $\begin{array}{c}3.92 \times \\
10^{-4}\end{array}$ & $\begin{array}{c}3.96 \times \\
10^{-1}\end{array}$ & $\begin{array}{c}3.39 \times \\
10^{-2}\end{array}$ & $\begin{array}{c}1.12 \times \\
10^{-1}\end{array}$ & \multirow{3}{*}{$\begin{array}{c}5.83 \times \\
10^{-1}\end{array}$} & \multirow{3}{*}{$\begin{array}{c}4.97 \times \\
10^{-2}\end{array}$} & \multirow{3}{*}{$\begin{array}{c}1.52 \times \\
10^{-1}\end{array}$} \\
\hline & & & Inhalation & $\begin{array}{c}7.64 \times \\
10^{-8}\end{array}$ & $\begin{array}{c}6.11 \times \\
10^{-8}\end{array}$ & $\begin{array}{c}6.11 \times \\
10^{-8}\end{array}$ & $\begin{array}{c}4.99 \times \\
10^{-2}\end{array}$ & $\begin{array}{c}4.06 \times \\
10^{-3}\end{array}$ & $\begin{array}{c}4.06 \times \\
10^{-3}\end{array}$ & & & \\
\hline & & & Dermal & $\begin{array}{c}1.75 \times \\
10^{-4}\end{array}$ & $\begin{array}{c}1.42 \times \\
10^{-5}\end{array}$ & $\begin{array}{c}1.42 \times \\
10^{-5}\end{array}$ & $\begin{array}{l}2.18 \times \\
10^{-5}\end{array}$ & $\begin{array}{c}1.75 \times \\
10^{-5}\end{array}$ & $\begin{array}{c}1.75 \times \\
10^{-5}\end{array}$ & & & \\
\hline & \multirow{3}{*}{ Sc3 } & \multirow{3}{*}{95.48} & Ingestion & $\begin{array}{c}1.22 \times \\
10^{-3}\end{array}$ & $\begin{array}{c}1.05 \times \\
10^{-4}\end{array}$ & $\begin{array}{c}3.45 \times \\
10^{-4}\end{array}$ & $\begin{array}{c}3.49 \times \\
10^{-1}\end{array}$ & $\begin{array}{c}2.99 \times \\
10^{-2}\end{array}$ & $\begin{array}{c}9.87 \times \\
10^{-2}\end{array}$ & \multirow{3}{*}{$\begin{array}{c}5.22 \times \\
10^{-1}\end{array}$} & \multirow{3}{*}{$\begin{array}{c}4.45 \times \\
10^{-2}\end{array}$} & \multirow{3}{*}{$\begin{array}{c}1.36 \times \\
10^{-1}\end{array}$} \\
\hline & & & Inhalation & $\begin{array}{c}6.73 \times \\
10^{-8}\end{array}$ & $\begin{array}{c}5.39 \times \\
10^{-8}\end{array}$ & $\begin{array}{c}5.39 \times \\
10^{-8}\end{array}$ & $\begin{array}{l}4.39 \times \\
10^{-2}\end{array}$ & $\begin{array}{c}3.58 \times \\
10^{-3}\end{array}$ & $\begin{array}{c}3.58 \times \\
10^{-3}\end{array}$ & & & \\
\hline & & & Dermal & $\begin{array}{c}1.54 \times \\
10^{-4}\end{array}$ & $\begin{array}{c}1.25 \times \\
10^{-5}\end{array}$ & $\begin{array}{c}1.25 \times \\
10^{-5}\end{array}$ & $\begin{array}{l}1.92 \times \\
10^{-5}\end{array}$ & $\begin{array}{c}1.54 \times \\
10^{-5}\end{array}$ & $\begin{array}{c}1.54 \times \\
10^{-5}\end{array}$ & & & \\
\hline & \multirow{3}{*}{ Sc4 } & \multirow{3}{*}{111.23} & Ingestion & $\begin{array}{c}1.42 \times \\
10^{-3}\end{array}$ & $\begin{array}{c}1.22 \times \\
10^{-4}\end{array}$ & $\begin{array}{c}4.02 \times \\
10^{-4}\end{array}$ & $\begin{array}{c}4.06 \times \\
10^{-1}\end{array}$ & $\begin{array}{c}3.48 \times \\
10^{-2}\end{array}$ & $\begin{array}{c}1.15 \times \\
10^{-1}\end{array}$ & \multirow{3}{*}{$\begin{array}{c}6.87 \times \\
10^{-1}\end{array}$} & \multirow{3}{*}{$\begin{array}{c}5.86 \times \\
10^{-2}\end{array}$} & \multirow{3}{*}{$\begin{array}{c}1.79 \times \\
10^{-1}\end{array}$} \\
\hline & & & Inhalation & $\begin{array}{c}7.84 \times \\
10^{-8}\end{array}$ & $\begin{array}{c}6.27 \times \\
10^{-8}\end{array}$ & $\begin{array}{c}6.27 \times \\
10^{-8}\end{array}$ & $\begin{array}{l}5.12 \times \\
10^{-2}\end{array}$ & $\begin{array}{c}4.17 \times \\
10^{-3}\end{array}$ & $\begin{array}{c}4.17 \times \\
10^{-3}\end{array}$ & & & \\
\hline & & & Dermal & $\begin{array}{c}1.79 \times \\
10^{-4}\end{array}$ & $\begin{array}{c}1.46 \times \\
10^{-5}\end{array}$ & $\begin{array}{c}1.46 \times \\
10^{-5}\end{array}$ & $\begin{array}{c}2.24 \times \\
10^{-5}\end{array}$ & $\begin{array}{c}1.79 \times \\
10^{-5}\end{array}$ & $\begin{array}{c}1.79 \times \\
10^{-5}\end{array}$ & & & \\
\hline & & & Ingestion & $\begin{array}{c}3.10 \times \\
10^{-3}\end{array}$ & $\begin{array}{c}2.66 \times \\
10^{-4}\end{array}$ & $\begin{array}{c}8.77 \times \\
10^{-4}\end{array}$ & $\begin{array}{c}8.86 \times \\
10^{-1}\end{array}$ & $\begin{array}{c}7.59 \times \\
10^{-2}\end{array}$ & $\begin{array}{c}2.51 \times \\
10^{-1}\end{array}$ & & & \\
\hline & $\mathrm{Sb} 1$ & 242.53 & Inhalation & $\begin{array}{c}1.71 \times \\
10^{-7}\end{array}$ & $\begin{array}{c}1.37 \times \\
10^{-7}\end{array}$ & $\begin{array}{c}1.37 \times \\
10^{-7}\end{array}$ & $\begin{array}{c}1.12 \times \\
10^{-1}\end{array}$ & $\begin{array}{c}9.09 \times \\
10^{-3}\end{array}$ & $\begin{array}{c}9.09 \times \\
10^{-3}\end{array}$ & $\begin{array}{c}5.64 \times \\
10^{-1}\end{array}$ & $\begin{array}{c}4.81 \times \\
10^{-2}\end{array}$ & $\begin{array}{c}1.47 \times \\
10^{-1}\end{array}$ \\
\hline & & & Dermal & $\begin{array}{c}3.91 \times \\
10^{-4}\end{array}$ & $\begin{array}{c}3.18 \times \\
10^{-5}\end{array}$ & $\begin{array}{c}3.18 \times \\
10^{-5}\end{array}$ & $\begin{array}{c}4.89 \times \\
10^{-5}\end{array}$ & $\begin{array}{c}3.91 \times \\
10^{-5}\end{array}$ & $\begin{array}{c}3.91 \times \\
10^{-5}\end{array}$ & & & \\
\hline & & & Ingestion & $\begin{array}{c}2.19 \times \\
10^{-3}\end{array}$ & $\begin{array}{c}1.88 \times \\
10^{-4}\end{array}$ & $\begin{array}{c}6.19 \times \\
10^{-4}\end{array}$ & $\begin{array}{c}6.25 \times \\
10^{-1}\end{array}$ & $\begin{array}{c}5.36 \times \\
10^{-2}\end{array}$ & $\begin{array}{c}1.77 \times \\
10^{-1}\end{array}$ & & & \\
\hline & $\mathrm{Sb} 2$ & 171.15 & Inhalation & $\begin{array}{c}1.21 \times \\
10^{-7}\end{array}$ & $\begin{array}{c}9.65 \times \\
10^{-8}\end{array}$ & $\begin{array}{c}9.65 \times \\
10^{-8}\end{array}$ & $\begin{array}{c}7.88 \times \\
10^{-2}\end{array}$ & $\begin{array}{c}6.41 \times \\
10^{-3}\end{array}$ & $\begin{array}{c}6.41 \times \\
10^{-3}\end{array}$ & $\begin{array}{c}5.13 \times \\
10^{-1}\end{array}$ & $\begin{array}{c}4.37 \times \\
10^{-2}\end{array}$ & $\begin{array}{c}1.34 \times \\
10^{-1}\end{array}$ \\
\hline & & & Dermal & $\begin{array}{c}2.76 \times \\
10^{-4}\end{array}$ & $\begin{array}{c}2.25 \times \\
10^{-5}\end{array}$ & $\begin{array}{c}2.25 \times \\
10^{-5}\end{array}$ & $\begin{array}{c}3.45 \times \\
10^{-5}\end{array}$ & $\begin{array}{c}2.76 \times \\
10^{-5}\end{array}$ & $\begin{array}{c}2.76 \times \\
10^{-5}\end{array}$ & & & \\
\hline & & & Ingestion & $\begin{array}{c}3.11 \times \\
10^{-3}\end{array}$ & $\begin{array}{c}2.66 \times \\
10^{-4}\end{array}$ & $\begin{array}{c}8.79 \times \\
10^{-4}\end{array}$ & $\begin{array}{c}8.88 \times \\
10^{-1}\end{array}$ & $\begin{array}{c}7.61 \times \\
10^{-2}\end{array}$ & $\begin{array}{c}2.51 \times \\
10^{-1}\end{array}$ & & & \\
\hline & Sb3 & 243.06 & Inhalation & $\begin{array}{c}1.71 \times \\
10^{-7}\end{array}$ & $\begin{array}{c}1.37 \times \\
10^{-7}\end{array}$ & $\begin{array}{c}1.37 \times \\
10^{-7}\end{array}$ & $\begin{array}{c}1.12 \times \\
10^{-1}\end{array}$ & $\begin{array}{c}9.11 \times \\
10^{-3}\end{array}$ & $\begin{array}{c}9.11 \times \\
10^{-3}\end{array}$ & $\begin{array}{c}5.14 \times \\
10^{-1}\end{array}$ & $\begin{array}{c}4.38 \times \\
10^{-2}\end{array}$ & $\begin{array}{c}1.34 \times \\
10^{-1}\end{array}$ \\
\hline & & & Dermal & $\begin{array}{c}3.92 \times \\
10^{-4}\end{array}$ & $\begin{array}{c}3.19 \times \\
10^{-5}\end{array}$ & $\begin{array}{c}3.19 \times \\
10^{-5}\end{array}$ & $\begin{array}{l}4.90 \times \\
10^{-5}\end{array}$ & $\begin{array}{c}3.92 \times \\
10^{-5}\end{array}$ & $\begin{array}{c}3.92 \times \\
10^{-5}\end{array}$ & & & \\
\hline & & & Ingestion & $\begin{array}{c}2.40 \times \\
10^{-4}\end{array}$ & $\begin{array}{c}2.06 \times \\
10^{-5}\end{array}$ & $\begin{array}{c}6.80 \times \\
10^{-5}\end{array}$ & $\begin{array}{c}8.01 \times \\
10^{-1}\end{array}$ & $\begin{array}{c}6.86 \times \\
10^{-2}\end{array}$ & $\begin{array}{c}2.27 \times \\
10^{-1}\end{array}$ & & & \\
\hline & Sc1 & 18.79 & Inhalation & $\begin{array}{c}1.32 \times \\
10^{-8}\end{array}$ & $\begin{array}{c}1.06 \times \\
10^{-8}\end{array}$ & $\begin{array}{c}1.06 \times \\
10^{-8}\end{array}$ & $\begin{array}{c}1.01 \times \\
10^{-1}\end{array}$ & $\begin{array}{c}8.22 \times \\
10^{-3}\end{array}$ & $\begin{array}{c}8.22 \times \\
10^{-3}\end{array}$ & $\begin{array}{c}9.02 \times \\
10^{-1}\end{array}$ & $\begin{array}{c}7.69 \times \\
10^{-2}\end{array}$ & $\begin{array}{c}2.35 \times \\
10^{-1}\end{array}$ \\
\hline & & & Dermal & $\begin{array}{l}3.03 \times \\
10^{-5}\end{array}$ & $\begin{array}{c}2.46 \times \\
10^{-6}\end{array}$ & $\begin{array}{c}2.46 \times \\
10^{-6}\end{array}$ & $\begin{array}{l}4.42 \times \\
10^{-5}\end{array}$ & $\begin{array}{c}3.53 \times \\
10^{-5}\end{array}$ & $\begin{array}{c}3.53 \times \\
10^{-5}\end{array}$ & & & \\
\hline & & & Ingestion & $\begin{array}{c}1.55 \times \\
10^{-4}\end{array}$ & $\begin{array}{c}1.33 \times \\
10^{-5}\end{array}$ & $\begin{array}{c}4.39 \times \\
10^{-5}\end{array}$ & $\begin{array}{c}5.18 \times \\
10^{-1}\end{array}$ & $\begin{array}{c}4.44 \times \\
10^{-2}\end{array}$ & $\begin{array}{c}1.46 \times \\
10^{-1}\end{array}$ & & & \\
\hline As & Sc2 & 12.14 & Inhalation & $\begin{array}{c}8.56 \times \\
10^{-9}\end{array}$ & $\begin{array}{c}6.85 \times \\
10^{-9}\end{array}$ & $\begin{array}{c}6.85 \times \\
10^{-9}\end{array}$ & $\begin{array}{c}6.52 \times \\
10^{-2}\end{array}$ & $\begin{array}{c}5.31 \times \\
10^{-3}\end{array}$ & $\begin{array}{c}5.31 \times \\
10^{-3}\end{array}$ & $\begin{array}{c}5.83 \times \\
10^{-1}\end{array}$ & $\begin{array}{c}4.97 \times \\
10^{-2}\end{array}$ & $\begin{array}{c}1.52 \times \\
10^{-1}\end{array}$ \\
\hline & & & Dermal & $\begin{array}{c}1.96 \times \\
10^{-5}\end{array}$ & $\begin{array}{c}1.59 \times \\
10^{-6}\end{array}$ & $\begin{array}{c}1.59 \times \\
10^{-6}\end{array}$ & $\begin{array}{c}2.85 \times \\
10^{-5}\end{array}$ & $\begin{array}{c}2.28 \times \\
10^{-5}\end{array}$ & $\begin{array}{c}2.28 \times \\
10^{-5}\end{array}$ & & & \\
\hline & Sc3 & 10.89 & Ingestion & $\begin{array}{c}1.39 \times \\
10^{-4}\end{array}$ & $\begin{array}{c}1.19 \times \\
10^{-5}\end{array}$ & $\begin{array}{c}3.94 \times \\
10^{-5}\end{array}$ & $\begin{array}{c}4.64 \times \\
10^{-1}\end{array}$ & $\begin{array}{c}3.98 \times \\
10^{-2}\end{array}$ & $\begin{array}{c}1.31 \times \\
10^{-1}\end{array}$ & $\begin{array}{c}5.22 \times \\
10^{-1}\end{array}$ & $\begin{array}{c}4.45 \times \\
10^{-2}\end{array}$ & $\begin{array}{c}1.36 \times \\
10^{-1}\end{array}$ \\
\hline
\end{tabular}


Ingestion $\mathrm{HQ}\left(\mathrm{HQ}_{\mathrm{ing}}\right)$ was most significant with respect to dermal $\mathrm{HQ}\left(\mathrm{HQ}_{\text {derm }}\right)$ and inhalation $\mathrm{HQ}\left(\mathrm{HQ}_{\text {inh }}\right)$. In children, the $\mathrm{HQ}_{\text {ing }}$ values corresponding to $\mathrm{Pb}$ in the corn-growing soils were lower than the $\mathrm{Pb} \mathrm{HQ}_{\text {ing }}$ values in the barley-growing soils. The $\mathrm{HQ}_{\text {ing }}$ values of $\mathrm{As}$ in the corn soils were higher than the $\mathrm{HQ}_{\text {ing }}$ values of $\mathrm{As}$ in the barley soils. In children, the HQ values of $\mathrm{Pb}$ and $\mathrm{As}$ in both crop soils for the three exposure pathways were higher than the HQ values in farmers and adults. Overall, the HQ values of $\mathrm{Pb}$ and As in maize and barley soils indicated that adverse health effects are unlikely $\left(\mathrm{HQ}_{\text {ing/derm/inh }}<1\right)$. The soil HI values of both crops were below the threshold value of 1 in all evaluated crop areas $(\mathrm{HI}<1)$, indicating that the non-carcinogenic adverse effect is negligible. However, the corn soil HI values were higher than the barley soil HI values, especially for children whose hazard index values are significantly higher than those of farmers and adults.

The carcinogenic risk level (CR) of As from ingestion of corn and barley cropping soil contaminated by this metalloid is higher in children than in farmers and adults. In children, the RC of As from ingestion of contaminated barley and corn soils varied from $2.05 \times 10^{-4}$ to $3.60 \times 10^{-4}$ (mean cancer risk). In farmers, the RC of As from ingestion of these contaminated soils ranged from $5.80 \times 10^{-5}$ low cancer risk) to $1.02 \times 10^{-4}$ (medium cancer risk) and in adults from $1.76 \times 10^{-5}$ to $3.09 \times 10^{-5}$ (low cancer risk). Regarding the CR levels of As by inhalation of contaminated soils from both types of crops for children, farmers and adults, qualified as medium cancer risk. The CR and TCR values were within the range of the safety limit, $10^{-6}$ to $10^{-4}$ (USEPA, 2011). However, the $\mathrm{CR}$ values for children As were close to the safe limit in the northern part of the study area, indicating a higher risk compared to where corn is predominant, indicating a higher risk with respect to farmers and adults (Table 4).

The bioconcentration of As in grain was determined through the bioconcentration factor (BCF) (Table 5). The bioconcentration capacity determined by the BCF values of As was higher in the barley than in the corn growing areas. The THQ of the As exceeded the target value of 1 in $100 \%$ of the barley and corn growing sampling sites. The THQ values of the for farmers and adults were lower than those recorded for children; however, they exceeded the target value of 1

Table 4. Carcinogenic risks to humans from soil arsenic

\begin{tabular}{|c|c|c|c|c|c|c|c|c|}
\hline \multirow{2}{*}{$\begin{array}{c}\text { Sampling } \\
\text { zones }\end{array}$} & \multirow{2}{*}{$\begin{array}{l}\mathrm{C}_{\text {CUL }} \\
\mathrm{mg} \mathrm{kg}^{-1}\end{array}$} & \multirow{2}{*}{$\begin{array}{l}\text { Pathways } \\
\text { exposure }\end{array}$} & \multicolumn{3}{|c|}{ CR } & \multicolumn{3}{|c|}{ TCR } \\
\hline & & & Children & Adult & Farmer & Children & Adult & Farmer \\
\hline \multirow{2}{*}{ Sc1 } & \multirow{2}{*}{18.79} & Ingestion & $3.60 \times 10^{-4}$ & $3.09 \times 10^{-5}$ & $1.02 \times 10^{-4}$ & \multirow{2}{*}{$1.87 \times 10^{-3}$} & \multirow{2}{*}{$1.54 \times 10^{-4}$} & \multirow{2}{*}{$2.25 \times 10^{-4}$} \\
\hline & & Inhalation & $4.79 \times 10^{-4}$ & $3.83 \times 10^{-4}$ & $3.83 \times 10^{-4}$ & & & \\
\hline \multirow{2}{*}{$\mathrm{Sc} 2$} & \multirow{2}{*}{12.14} & Ingestion & $2.33 \times 10^{-4}$ & $2.00 \times 10^{-5}$ & $6.59 \times 10^{-5}$ & \multirow{2}{*}{$1.21 \times 10^{-3}$} & \multirow{2}{*}{$9.96 \times 10^{-5}$} & \multirow{2}{*}{$1.46 \times 10^{-4}$} \\
\hline & & Inhalation & $3.10 \times 10^{-4}$ & $2.48 \times 10^{-4}$ & $2.48 \times 10^{-4}$ & & & \\
\hline \multirow{2}{*}{ Sc3 } & \multirow{2}{*}{10.89} & Ingestion & $2.09 \times 10^{-4}$ & $1.79 \times 10^{-5}$ & $5.91 \times 10^{-5}$ & \multirow{2}{*}{$1.09 \times 10^{-3}$} & \multirow{2}{*}{$8.93 \times 10^{-5}$} & \multirow{2}{*}{$1.30 \times 10^{-4}$} \\
\hline & & Inhalation & $2.78 \times 10^{-4}$ & $2.22 \times 10^{-4}$ & $2.22 \times 10^{-4}$ & & & \\
\hline \multirow{2}{*}{ Sc4 } & \multirow{2}{*}{14.32} & Ingestion & $2.75 \times 10^{-4}$ & $2.35 \times 10^{-5}$ & $7.77 \times 10^{-5}$ & \multirow{2}{*}{$1.43 \times 10^{-3}$} & \multirow{2}{*}{$1.17 \times 10^{-4}$} & \multirow{2}{*}{$1.72 \times 10^{-4}$} \\
\hline & & Inhalation & $3.65 \times 10^{-4}$ & $2.92 \times 10^{-4}$ & $2.92 \times 10^{-4}$ & & & \\
\hline \multirow{2}{*}{ Sb1 } & \multirow{2}{*}{11.76} & Ingestion & $2.26 \times 10^{-4}$ & $1.9 \times 10^{-5}$ & $6.38 \times 10^{-5}$ & \multirow{2}{*}{$1.17 \times 10^{-3}$} & \multirow{2}{*}{$9.65 \times 10^{-5}$} & \multirow{2}{*}{$1.41 \times 10^{-4}$} \\
\hline & & Inhalation & $3.00 \times 10^{-4}$ & $2.40 \times 10^{-4}$ & $2.40 \times 10^{-4}$ & & & \\
\hline \multirow{2}{*}{$\mathrm{Sb} 2$} & \multirow{2}{*}{10.69} & Ingestion & $2.05 \times 10^{-4}$ & $1.76 \times 10^{-5}$ & $5.80 \times 10^{-5}$ & \multirow{2}{*}{$1.07 \times 10^{-3}$} & \multirow{2}{*}{$8.77 \times 10^{-5}$} & \multirow{2}{*}{$1.28 \times 10^{-4}$} \\
\hline & & Inhalation & $2.73 \times 10^{-4}$ & $2.18 \times 10^{-4}$ & $2.18 \times 10^{-4}$ & & & \\
\hline \multirow{2}{*}{ Sb3 } & \multirow{2}{*}{10.70} & Ingestion & $2.05 \times 10^{-4}$ & $1.76 \times 10^{-5}$ & $5.80 \times 10^{-5}$ & & & \\
\hline & & Inhalation & $2.73 \times 10^{-4}$ & $2.18 \times 10^{-4}$ & $2.18 \times 10^{-4}$ & & & \\
\hline
\end{tabular}


Table 5. Bioconcentration factor and carcinogenic risks to humans from grain arsenic.

\begin{tabular}{|c|c|c|c|c|c|c|c|}
\hline \multirow{2}{*}{$\begin{array}{l}\text { Sampling } \\
\text { sites }\end{array}$} & \multirow{2}{*}{$\mathrm{BCF}$} & \multicolumn{3}{|c|}{$\mathrm{THQ}$} & \multicolumn{3}{|c|}{$\mathrm{CR}$} \\
\hline & & Children & Adult & Farmer & Children & Adult & Farmer \\
\hline Gc1 & 0.005 & 2.88 & 1.41 & 1.41 & $1.30 \times 10^{-3}$ & $6.32 \times 10^{-4}$ & $6.32 \times 10^{-4}$ \\
\hline $\mathrm{Gc2}$ & 0.009 & 3.41 & 1.66 & 1.66 & $1.53 \times 10^{-3}$ & $7.48 \times 10^{-4}$ & $7.48 \times 10^{-4}$ \\
\hline Gc3 & 0.007 & 2.18 & 1.06 & 1.06 & $9.80 \times 10^{-4}$ & $4.78 \times 10^{-4}$ & $4.78 \times 10^{-4}$ \\
\hline Gc4 & 0.010 & 4.43 & 2.16 & 2.16 & $2.00 \times 10^{-3}$ & $9.73 \times 10^{-4}$ & $9.73 \times 10^{-4}$ \\
\hline $\mathrm{Gb} 1$ & 0.016 & 5.83 & 2.84 & 2.84 & $2.62 \times 10^{-3}$ & $1.28 \times 10^{-3}$ & $1.28 \times 10^{-3}$ \\
\hline $\mathrm{Gb} 2$ & 0.014 & 4.55 & 2.22 & 2.22 & $2.05 \times 10^{-3}$ & $9.98 \times 10^{-4}$ & $9.98 \times 10^{-4}$ \\
\hline Gb3 & 0.018 & 5.81 & 2.84 & 2.84 & $2.62 \times 10^{-3}$ & $1.28 \times 10^{-3}$ & $1.28 \times 10^{-3}$ \\
\hline
\end{tabular}

in $100 \%$ of the sampling sites for both crops. The sampling sites with barley cultivation quantified high non-carcinogenic risk, indicating a level of exposure sufficient to cause non-carcinogenic adverse health risks over a lifetime (USEPA, 1995). The carcinogenic risk of As in cereals exceeded the acceptable risk level of $10^{-6}$ in all sampling zones (USEPA, 2011).

\section{DISCUSSION}

Increasing presence of heavy metals and metalloids in water, soil and food is a problem of great environmental, agricultural and health concern worldwide (Yang et al., 2007). The availability of good quality water for agriculture is decreasing due to the strong anthropogenic pressures (e.g., poor waste management, mining and agrochemicals) on aquatic systems. The soil and water contamination is directly related to crosscontamination of food through irrigation. The accumulation of heavy metals and metalloids in agricultural soil is of increasing concern to today's society due to the highly toxic and carcinogenic nature of these elements (Basha et al., 2014). The results obtained reveal that only the $\mathrm{Pb}$ concentrations in the soils where both cereals are grown greatly exceeded the Peruvian standard soil EQS (Ministry of the Environment, 2017) and the FAO/WHO threshold values (FAO/WHO, 1993).

Spatial distribution of heavy metals and metalloids in the agricultural soils analyzed in this study depends on the natural and anthropogenic sources. The Andean Mesozoic belt in central Peru represents a rich source of heavy metals and metalloids. Because of this, the intensive exploitation of these minerals began more than a century ago with the consequent generation of waste that ended up contaminating the soil. The contamination of soil and plants at a global level is widely demonstrated in several studies (Ordóñez et al., 2011; Chaoua et al., 2018; Doabi et al., 2018) and very rarely in the soils and food grains in Peru. The high concentrations of $\mathrm{Pb}$ in the corn and barley soils recorded in this study are mainly due to the transport of this metal through the waters of the Mantaro River. Monitoring by the Ministry of Agriculture Ministry of Agriculture (2010) of this river reveals high concentrations of heavy metals and metalloids that exceed the water EQS. However, during the dry season, the Mantaro River waters are used for irrigation of large agricultural areas throughout the basin.

Corn and barley are important food crops in the diet of the Andean population, mainly. Corn has been implicated as an important route of exposure to heavy metals and metalloids, especially in the areas with strong mining influence (Apablaza et al., 2017). In grains of these cereals, the heavy metals with toxicological effect such as $\mathrm{Pb}$ were not detected. Therefore, the consumption of these cereals from the study area does not represent a danger to human health. As showed mean concentrations lower than the FAO/WHO and EPA safety limits (FAO/WHO, 2011; EPA, 2004). In addition, there is no maximum permitted level of As in cereals and related products established by Codex alimentarius or the European Union (Joint FAO/WHO Food Standards Programme, 2001; Branco et al., 2015). However, the exposure of crops to As, even at very low concentrations, can cause many morphological, physiological and 
biochemical changes. The results also reveal that the concentration of heavy metals in grains is affected by the chemical speciation of heavy metals in the soil, the soil properties and the genetic characteristics of the crops (Adekiya et al., 2018).

The human exposure to heavy metals and metalloids through ingestion, dermal contact and inhalation of soil and ingestion of contaminated food is a more frequent health problem worldwide (Wang et al., 2019). The HQ values varied by route of exposure, daily intake, age and soil type. The $\mathrm{Pb} \mathrm{HQ}_{\text {ing }}$ values in children, farmers and adults revealed that adverse health effects are unlikely. However, results show that children have a higher lead intake than farmers and adults. Many studies reveal that the lead intake can cause major changes in several biological processes at the cellular and molecular level, such as alteration of the composition of biomembranes, interference with the functioning of enzyme systems, decoupling of biochemical reactions and blocking of release of neurotransmitters and encephalopathies (Dórea, 2019). There is great evidence about the association of the $\mathrm{Pb}$ exposure with several disorders or diseases. In the gestation period, the exposure to this heavy metal can cause miscarriages, premature births, low birth weight and neonatal deaths (Claus Henn et al., 2016; Sanders et al., 2018), due to the great facility of $\mathrm{Pb}$ to cross the placental barrier. In children, the exposure to $\mathrm{Pb}$ causes learning and behavior disorders, lowered intelligence quotient, and hearing disorders (Pebe et al., 2008). Other diseases associated with the $\mathrm{Pb}$ exposure are diabetes, hypertension and cardiovascular disease (Thayer et al., 2012).

The exposure routes reveal that ingestion of soil from the arsenic-contaminated cereal crops is the main pathway of exposure to this metalloid, followed by the inhalation pathway. In children, the HQ from ingestion and inhalation of arseniccontaminated cereal crop soil was higher than the hazard quotient for farmers and adults. Global studies report that the arsenic toxicity affects mainly the digestive, nervous, renal, and skin systems (Mendez et al., 2016; Claus Henn et al., 2016). The health risk indices for ingestion $\left(\mathrm{HI}_{\text {ing }}\right)$ of the soil contaminated by $\mathrm{Pb}$ and As were lower than the unit for children, farmers and adults. The $\mathrm{CR}$ assessment for $\mathrm{As}$ and $\mathrm{Pb}$ ingestion in corn and barley grains studied was greater than 1 in a million $\left(10^{-6}\right)$, indicating a significant risk according to USEPA (USEPA, 2007).

\section{CONCLUSIONS}

The soils of the Mantaro River valley in central Peru are exposed to contamination by heavy metals and metalloids, because large agricultural areas are irrigated with water from the Mantaro River (a river with a high content of toxic elements) during the dry season. The decreasing order of average concentrations of heavy metals and arsenic in the soil samples from corn and barley cultivation was: $\mathrm{Fe}>\mathrm{Zn}>\mathrm{Pb}>\mathrm{Cu}>$ As. The concentrations of $\mathrm{Fe}$ and $\mathrm{As}$ in the corn cultivation soils were higher than the concentrations of these elements in the barley cultivation soils. Similar behaviors were presented by the $\mathrm{Cu}, \mathrm{Pb}$ and $\mathrm{Zn}$ concentrations in the barley soils with respect to the concentrations of these elements in the corn soils. Fe was the only heavy metal in corn grains that presented average concentrations higher than the average concentrations in barley grains. The average concentrations of $\mathrm{Cu}, \mathrm{Zn}$ and $\mathrm{As}$ in barley grains were significantly higher than the average concentrations of these heavy metals and metalloids in corn grains. The PERMANOVA analysis showed that the effect of the type of crop and the sampling sector influence the concentrations of $\mathrm{Pb}, \mathrm{Cu}, \mathrm{Fe}, \mathrm{Zn}$ and $\mathrm{As}$ in soil and grains significantly $(\mathrm{p}<0.05)$.

Health risk assessment showed that the order of exposure was children $>$ farmers $>$ adults. Out of the three routes of exposure to heavy metals and arsenic in soil, ingestion was the main route of exposure, followed by the respiratory exposure and finally by dermal contact exposure. The evaluation of the carcinogenic and non-carcinogenic risks due to the exposure to heavy metals and metalloids in crop soils and corn and barley grains in children, farmers and adults showed that the route of ingestion was the most representative. The soil HI values of both cereals were less than unity in all crop areas evaluated $(\mathrm{HI}<1)$, indicating that the non-carcinogenic adverse effect is negligible. The carcinogenic risk level of As from the ingestion of corn and barley crop soils contaminated by this metalloid is higher in children than in farmers and adults. The carcinogenic risk of As in cereals exceeded the acceptable risk level of $10^{-6}$ in all sampling zones.

These findings suggest the implementation of strategies for the regular monitoring of contamination by toxic elements of soils and food crops in order to prevent the health problems caused by the ingestion of contaminated vegetables, 
especially As. It is also recommended that farmers in the study area be informed about the appropriate use of agrochemicals and that they analyze the soils of their agricultural fields before each growing season.

\section{Acknowledgments}

We express our gratitude to the Universidad Nacional del Centro del Peru for the financial support.

\section{REFERENCES}

1. Adekiya, A.O., Oloruntoba, A.P., Ojeniyi, S.O., \& Ewulo, B.S. 2018. Heavy metal composition of maize and tomato grown on contaminated soils. Open Agriculture, 3(1), 414-426. https://doi. org/10.1515/opag-2018-0046

2. Agriculture Ministry. 2008. Regional agricultural sector strategic plan 2009 - 2015. Regional Direction of Agriculture Junin. Retrieved from https:// www.minagri.gob.pe/portal/download/pdf/conocenos/transparencia/planes_estrategicos_regionales/ junin.pdf

3. Al-bagawi, A.H. (2019). Assessment of Trace Elements Contamination of Irrigation Water and $\mathrm{Ag}$ ricultural Soil in Hail Region, Saudi Arabia. IOSR Journal of Applied Chemistry, 12(1), 7-15. https:// doi.org/10.9790/5736-1201010715

4. Amin, N., Hussain, A., Alamzeb, S., \& Begum, S. 2013. Accumulation of heavy metals in edible parts of vegetables irrigated with waste water and their daily intake to adults and children, District Mardan , Pakistan. Food Chemistry, 136(3-4), 1515-1523. https://doi.org/10.1016/j.foodchem.2012.09.058

5. Antoniadis, V., Golia, E.E., Liu, Y.T., Wang, S.L., Shaheen, S.M., \& Rinklebe, J. 2019. Soil and maize contamination by trace elements and associated health risk assessment in the industrial area of Volos, Greece. Environment International, 124, 79-88. https://doi.org/10.1016/j.envint.2018.12.053

6. Antoniadis, V., Shaheen, S.M., Boersch, J., Frohne, T., Du Laing, G., \& Rinklebe, J. 2017. Bioavailability and risk assessment of potentially toxic elements in garden edible vegetables and soils around a highly contaminated former mining area in Germany. Journal of Environmental Management, 186, 192-200. https://doi.org/10.1016/j.jenvman.2016.04.036

7. Apablaza, H.V., Carrasco, F.C., Sandoval, C.P., \& Cortés, C. 2017. Transfer of arsenic in the watersoil-maize system of Zea mays l. of cultivated in the quebrada de Camiña, northern Chile. Revista de la Sociedad Química del Perú, 83(1), 52-64.
8. APHA. 2012.Standard Methods for Examination of Water and Wastewater; American Public Health Association: Washington, DC, USA.

9. Arisseto-Bragotto, A.P., Feltes, M.M.C., \& Block, J.M. 2017. Food quality and safety progress in the Brazilian food and beverage industry: Chemical hazards. Food Quality and Safety, 1(2), 117-129. https://doi.org/10.1093/fqsafe/fyx009

10. Basha, A.M., Yasovardhan, N., Satyanarayana, S.V., Reddy, G.V. S., \& Vinod Kumar, A. 2014. Trace metals in vegetables and fruits cultivated around the surroundings of Tummalapalle uranium mining site, Andhra Pradesh, India. Toxicology Reports, 1, 505512. https://doi.org/10.1016/j.toxrep.2014.07.011

11. Branco, A.P., Amaral de Souza, G., Cardoso, G.V., De Andrade, C.C., Amaral de Lima, W.E., Dias, M.F., Hideto, Y.C.,Bohac, F.E., Guimarăes, G.L. 2015. Assessing arsenic, cadmium, and lead contents in major crops in Brazil for food safety purposes. Journal of Food Composition and Analysis, 37, 143-150. https://doi.org/10.1016/j.jfca.2014.08.004

12. Bui, A.T.K., Nguyen, H.T.H., Nguyen, M.N., Tran, T.H.T., Vu, T.V., Nguyen, C.H., \& Reynolds, H.L. 2016. Accumulation and potential health risks of cadmium, lead and arsenic in vegetables grown near mining sites in Northern Vietnam. Environmental Monitoring and Assessment, 188(9). https://doi. org/10.1007/s10661-016-5535-5

13. Cai, Q., Long, M., Zhu, M., Zhou, Q., Zhang, L., \& Liu, J. 2009. Food chain transfer of cadmium and lead to cattle in a lead - zinc smelter in Guizhou, China. Environmental Pollution, 157(11), 30783082. https://doi.org/10.1016/j.envpol.2009.05.048

14. Chaoua, S., Boussaa, S., El Gharmali, A., \& Boumezzough, A. 2018. Impact of irrigation with wastewater on accumulation of heavy metals in soil and crops in the region of Marrakech in Morocco. Journal of the Saudi Society of Agricultural Sciences, 18(4), 429-436. https://doi.org/10.1016/j. jssas.2018.02.003

15. Claus Henn, B., Ettinger, A.S., Hopkins, M.R., Jim, R.,Amarasiriwardena, C., Christiani, D.C., Coult, B.A., Bellinger, D.C., Wright, R.O. 2016. Prenatal arsenic exposure and birth outcomes among a population residing near a mining-related superfund site. Environmental Health Perspectives, 124(8), 1308-1315. https://doi.org/10.1289/ehp.1510070

16. Doabi, S.A., Karami, M., Afyuni, M., \& Yeganeh, M. 2018. Pollution and health risk assessment of heavy metals in agricultural soil, atmospheric dust and major food crops in Kermanshah province, Iran. Ecotoxicology and Environmental Safety, 163, 153164. https://doi.org/10.1016/j.ecoenv.2018.07.057

17. Dórea, J.G. 2019. Environmental exposure to lowlevel lead $(\mathrm{Pb})$ co-occurring with other neurotoxicants in early life and neurodevelopment of children. 
Environmental Research, 177, 108641. https://doi. org/10.1016/j.envres.2019.108641

18. EPA. 2000. Science Policy Council Handbook: Risk characterization. Retrieved from https:/www.epa. gov/risk/risk-characterization-handbook

19. EPA. 2004. Risk assessment guidance for superfund (RAGS). Volume I. Human health evaluation manual (HHEM). Part E. Supplemental guidance for dermal risk assessment. EPA. Washington, DC 20460. https://doi.org/EPA/540/1-89/002

20. Fan, Y., Li, H., Xue, Z., Zhang, Q., \& Cheng, F. 2017. Accumulation characteristics and potential risk of heavy metals in soil-vegetable system under greenhouse cultivation condition in Northern China. Ecological Engineering, 102, 367-373. https://doi. org/10.1016/j.ecoleng.2017.02.032

21. FAO/WHO. 1993. Evaluation of certain food additives and contaminants. Technical report series 837. World Health Organization. Geneva. Retrieved from https://apps.who.int/iris/handle/10665/204410

22. FAO/WHO. 2011. Evaluation of certain food additives and contaminants. Food and Agriculture Organization of the United Nations and World Health Organization (Vol. 960). Retrieved from https:// apps.who.int/iris/bitstream/handle/10665/44515/ WHO_TRS_960_eng.pdf?sequence $=1$

23. França, F.C.S.S., Albuuerque, A.M.A., Almeida, A.C., Silveira, P.B., Filho, C., Hazin, C. A., \& Honorato, E.V. 2017. Heavy metals deposited in the culture of lettuce (Lactuca sativa L.) by the influence of vehicular traffic in Pernambuco, Brazil. Food Chemistry, 215, 171-176. https://doi.org/10.1016/j. foodchem.2016.07.168

24. Geophysical Institute of Peru. 2010. Seasonal rainfall and temperature forecast in the Mantaro River basin for application in agriculture. Retrieved from https://doi.org/10.1017/CBO9781107415324.004

25. Gottfried, J.L., Harmon, R.S., De Lucia, F.C., \& Miziolek, A.W. 2009. Multivariate analysis of laserinduced breakdown spectroscopy chemical signatures for geomaterial classification. Spectrochimica Acta - Part B Atomic Spectroscopy, 64(10), 10091019. https://doi.org/10.1016/j.sab.2009.07.005

26. Haidong, Z., Biao, H., Linlin, D., Wenyou, H., Saleem, A. M., \& Mingkai, Q. 2017. Accumulation, sources and health risks of trace metals in elevated geochemical background soils used for greenhouse vegetable production in southwestern China. Ecotoxicology and Environmental Safety, 137, 233239. https://doi.org/10.1016/j.ecoenv.2016.12.010

27. Hang, X., Wang, H., Zhou, J., Ma, C., Du, C., \& Chen, X. 2009. Risk assessment of potentially toxic element pollution in soils and rice (Oryza sativa) in a typical area of the Yangtze River Delta. Environmental Pollution, 157(8-9), 2542-2549. https://doi. org/10.1016/j.envpol.2009.03.002
28. Joint FAO/WHO Food Standards Programme. 2001. Report of the 33rd Session of the Codex Committee on Food Additives and Contaminants. Hague, The Netherlands: ÂC The Authors. All rights reserved. https://doi.org/10.1093/mp/sss069

29. Kamunda, C., Mathuthu, M., \& Madhuku, M. (2016). Health risk assessment of heavy metals in soils from witwatersrand gold mining basin, South Africa. International Journal of Environmental Research and Public Health, 13(7). https://doi. org/10.3390/ijerph13070663

30. Khan, A., Khan, S., Khan, M.A., Aamir, M., Ullah, H., Nawab, J., Rehman, I.U., Shah, J. 2019. Heavy metals effects on plant growth and dietary intake of trace metals in vegetables cultivated in contaminated soil. International Journal of Environmental Science and Technology, 16(5), 2295-2304. https:// doi.org/10.1007/s13762-018-1849-X

31. Khan, M.U., Malik, R.N., \& Muhammad, S. 2013. Human health risk from Heavy metal via food crops consumption with wastewater irrigation practices in Pakistan. Chemosphere, 93(10), 2230-2238. https:// doi.org/10.1016/j.chemosphere.2013.07.067

32. Kumar, A., \& Prasad, M.N.V. 2018. Plant-lead interactions: Transport, toxicity, tolerance, and detoxification mechanisms. Ecotoxicology and Environmental Safety, 166(April), 401-418. https://doi. org/10.1016/j.ecoenv.2018.09.113

33. Mendez, M.A., González-Horta, C., SánchezRamírez, B., Ballinas-Casarrubias, L., Cerón, R.H., Morales, D.V., Baeza Terrazas, F.A., Ishida, M.C., Gutiérrez-Torres, D.S., Saunders, R.J., Drobná, Z., Fry, R.C., Buse, J.B., Loomis, D., García-Vargas, G.G., Del Razo, L.M., Stýblo, M. 2016. Chronic exposure to arsenic and markers of cardiometabolic risk: A cross-sectional study in Chihuahua, Mexico. Environmental Health Perspectives, 124(1), 104111. https://doi.org/10.1289/ehp.1408742

34. Ministry of Agriculture. 2010. Assessment of surface water resources in the Mantaro River watershed. Lima.

35. Ministry of the Environment. Environmental quality standards for soil in Peru, El Peruano 2017. Peru. Retrieved from http:/www.minam.gob.pe/wp-content/uploads/2017/12/DS_011-2017-MINAM.pdf

36. National Water Authority. 2014. Participatory monitoring of water quality in Lake Chinchaycocha (flood season) Junin-Pasco.

37. Ordóñez, A., Álvarez, R., Charlesworth, S., De Miguel, E., \& Loredo, J. 2011. Risk assessment of soils contaminated by mercury mining, Northern Spain. Journal of Environmental Monitoring, 13(1), 128-136. https://doi.org/10.1039/c0em00132e

38. Pebe, G., Villa, H., Escate, L., \& Cervantes, G. 2008. Blood lead levels in newborns in La Oroya, 2004-2005. Revista Peruana de Medicina 
Experimental y Salud Publica, 25(4), 355-360.

39. Rai, P. K., Lee, S. S., Zhang, M., Tsang, Y. F., \& Kim, K. H. 2019. Heavy metals in food crops: Health risks, fate, mechanisms, and management. Environment International. 125, 365-385. https:// doi.org/10.1016/j.envint.2019.01.067

40. Sanders, A. P., Svensson, K., Gennings, C., Burris, H. H., Oken, E., Amarasiriwardena, C., Basnet, P., Pizano-Zarate, M.L., Schnaas, L., Tamayo.Ortiz, M., Baccarelli, A.A., Satlin, L.M., Wright, R.O., Tellez-Rojo, M. M. 2018. Prenatal lead exposure modifies the effect of shorter gestation on increased blood pressure in children. Environment International, 120, 464-471. https://doi.org/10.1016/j. envint.2018.08.038

41. Shah, A. H., Shahid, M., Khalid, S., Natasha, Shabbir, Z., Bakhat, H. F., Murtaza, B., Farooq, A., Akram, M., Shah G.M., Nasim, W. Niazi, N. K. 2020. Assessment of arsenic exposure by drinking well water and associated carcinogenic risk in peri-urban areas of Vehari, Pakistan. Environmental Geochemistry and Health, 42(1), 121-133. https:// doi.org/10.1007/s10653-019-00306-6

42. Shahid, M., Dumat, C., Khalid, S., Rabbani, F., Bakr, A., Farooq, U., Amjad M., Abbas, G., Niazi, N.K. 2018. Foliar uptake of arsenic nanoparticles by spinach : an assessment of physiological and human health risk implications Foliar uptake of arsenic nanoparticles by spinach: an assessment of physiological and human health risk implications, 26, 20121-20131. https://doi.org/10.1007/ s11356-018-3867-0

43. Thayer, K. A., Heindel, J. J., Bucher, J. R., \& Gallo, M. A. 2012. Role of Environmental Chemicals in Diabetes and Obesity : A National Toxicology Program Workshop Review. Environmental Health Perspectives, 120(6), 779-789.

44. USEPA. 2011. Exposure Factors Handbook: 2011 Edition. U.S. Environmental Protection Agency, EPA/600/R-(September), 1-1466. https://doi.org/ EPA/600/R-090/052F

45. USEPA. 1996. Test methods for evaluating solid waste: physical/chemical methods compendium (SW-846). Retrieved from https://www.epa.gov/hwsw846/table-contents-test-methods-evaluating-solidwaste-physicalchemical-methods-compendium-sw

46. USDA. 2000. Heavy Metal Soil Contamination. United States Departament of Agriculture. Soil quality - Urban Technical Note $\mathrm{N}^{\circ} 3$. Retrieved from https://www.nrcs.usda.gov/Internet/FSE_ DOCUMENTS/nrcs142p2_053279.pdf

47. USEPA. 1995. EPA Region III Risk-Based concentration table. Retrieved from https://hwbdocuments. env.nm.gov/Los $\% 20$ Alamos $\% 20$ National $\% 20$
Labs/References/9642.PDF

48. USEPA. 2007. Framework for Metals Risk Assessment. EPA 120/R-07/001. Environmental Protection. Retrieved from https://www.epa.gov/risk/ framework-metals-risk-assessment

49. USEPA. 2011. Screening Levels (RSL) for chemical contaminants at superfund sites. U.S. Environmental Protection Agency. Retrieved from https://www. epa.gov/risk/regional-screening-levels-rsls

50. Wang, N., Han, J., Wei, Y., Li, G., \& Sun, Y. 2019. Potential ecological risk and health risk assessment of heavy metals and metalloid in soil around Xunyang mining areas. Sustainability, 11(18). https:// doi.org/10.3390/su11184828

51. Woldetsadik, D., Drechsel, P., Keraita, B., Itanna, F., \& Gebrekidan, H. 2017. Heavy metal accumulation and health risk assessment in wastewater-irrigated urban vegetable farming sites of Addis Ababa, Ethiopia. International Journal of Food Contamination, 4(1). https://doi.org/10.1186/s40550-017-0053-y

52. Yang, Q. W., Li, H., \& Long, F.Y. 2007. Heavy metals of vegetables and soils of vegetable bases in Chongqing, Southwest China. Environmental Monitoring and Assessment, 130(1-3), 271-279. https://doi.org/10.1007/s10661-006-9395-2

53. Yang, Y., Zhang, F.S., Li, H F., \& Jiang, R.F. 2009. Accumulation of cadmium in the edible parts of six vegetable species grown in Cd-contaminated soils. Journal of Environmental Management, 90(2), 1117-1122. https://doi.org/10.1016/j. jenvman.2008.05.004

54.Zhao, Q., Wang, Y., Cao, Y., Chen, A., Ren, M., Ge, Y., Yu, Z., Wan, S., Hu, A., Bo, Q., Ruan, L., Chen, H., Qin,S., Chen, W., Hu, C., Tao, F., Xu, D., Xu, J., Wen, L., Li, L. 2014. Science of the Total Environment Potential health risks of heavy metals in cultivated topsoil and grain, including correlations with human primary liver, lung and gastric cancer, in Anhui province, Eastern China. Science of the Total Environmental, 471, 340-347. https:// doi.org/10.1016/j.scitotenv.2013.09.086

55. Zhou, H., Yang, W.T., Zhou, X., Liu, L., Gu, J.F., Wang, W.L., Zou, J.L., Tian, T., Peng, P.Q., Liao, B.H. 2016. Accumulation of heavy metals in vegetable species planted in contaminated soils and the health risk assessment. International Journal of Environmental Research and Public Health, 13(3). 289. https://doi.org/10.3390/ijerph13030289

56. Zhu, Y., Yu, H., Wang, J., Fang, W., Yuan, J., \& Yang, Z. 2007. Heavy metal accumulations of 24 asparagus bean cultivars grown in soil contaminated with $\mathrm{Cd}$ alone and with multiple metals $(\mathrm{Cd}, \mathrm{Pb}$, and $\mathrm{Zn})$. Journal of Agricultural and Food Chemistry, 55(3), 1045-1052. https://doi.org/10.1021/jf062971p 